\title{
Profile of snakebite victims reported in a public teaching hospital: a cross-sectional study
}

\author{
Perfil das vítimas de acidente ofídico notificadas em um \\ hospital público de ensino: estudo transversal \\ Perfil de las víctimas de accidentes ofídicos notificados en un \\ hospital público docente: estudio transversal
}

How to cite this article:

Souza LA, Silva AD, Chavaglia SRR, Dutra CM, Ferreira LA. Profile of snakebite victims reported in a public teaching hospital: a cross-sectional study. Rev Esc Enferm USP. 2021;55:e03721. doi: https://doi.org/10.1590/S1980-220X2020007003721

Lucélia Aline de Souza ${ }^{1}$

Amanda Diniz Silva ${ }^{1}$

Suzel Regina Ribeiro Chavaglia ${ }^{2}$

D Cíntia Machado Dutra ${ }^{1}$

D Lúcia Aparecida Ferreira ${ }^{2}$

${ }^{1}$ Universidade Federal do Triângulo Mineiro, Uberaba, MG, Brazil.

${ }^{2}$ Universidade Federal do Triângulo Mineiro, Departamento de Enfermagem em Assistência Hospitalar, Uberaba, MG, Brazil.

\begin{abstract}
Objective: To understand the epidemiological and clinical profile of snakebite victims in a public teaching hospital. Method: Exploratory, descriptive, cross-sectional study with a quantitative approach conducted in a public hospital in the Triângulo Sul region of Minas Gerais state, Brazil. The data were collected from medical records and compulsory case report forms of patients admitted in the Emergency Service from June 2018 to May 2019. The data were descriptively analyzed and presented in tables. Results: The 137 patients were predominantly male (74.5\%), rural workers $(33.4 \%)$, in their working age (mean of 43.49 years), and in rural areas (87.6\%). Bothrops was the most common genus (70.8\%), and most occurrences were classified as mild (53.3\%). The most performed treatment was snake antivenom administration (73\%). Conclusion: Snakebite victims were mostly men in their working age and rural workers. Bothrops bites and mild occurrences were prevalent. Most treatments employed the appropriate snake antivenom These occurred mostly in rural areas. The prevalent bitten body parts were feet, legs, and hands. Care was provided in less than six hours.
\end{abstract}

DESCRIPTORS

Health Profile; Snake Bites; Snake Venoms; Emergency Medical Services; Emergency Nursing. 


\section{INTRODUCTION}

Snakebites or envenomation by snakes are of crucial importance in Brazil and worldwide. These have been reincluded in the list of neglected tropical diseases by the World Health Organization (WHO) in $2017^{(1)}$.

Bites by venomous snakes are a major public health problem in tropical and subtropical countries ${ }^{(2-4)}$. Brazil presents the highest annual rates of accidents involving such snakes ${ }^{(3,5-6)}$. Snakebites have impacts on the economy and society due to morbidities and mortalities such as increased amputation rate and other sequels of such envenomation ${ }^{(7)}$.

A venomous animal is defined as having venom and a structure for inoculation, which, in venomous snakes, are named fangs. Snakes have four types of dentition and are thus classified as aglyphous, opisthoglyphous, proteroglyphous, or solenoglyphous. Only proteroglyphous and solenoglyphous have fangs with its venom channel connected to the venom glands ${ }^{(8-9)}$. The characteristics of venomous snakes, except for coral snakes, are possessing pit organ, triangular head with small scales, slit pupil, solenoglyphous and proteroglyphous dentitions. The main snakes related to accidents with humans in Brazil are part of two families: Viperidae, represented mainly by the genera Bothrops (jararaca, neuwiedi), Crotalus (rattlesnake) and Lachesis (Lachesis muta), and Elapidae, represented by the genus Micrurus (coral snake). The venom of venomous Bothrops have three actions: proteolytic, coagulating, and hemorrhagic. Crotalus venom has neurotoxic, myotoxic, and coagulating actions. Lachesis venom presents proteolytic, hemorrhagic, coagulating, and neurotoxic actions. As for the Elapidae, their venom has neurotoxic and myotoxic action ${ }^{(10-12)}$.

The treatment of venomous snakebite is performed with intravenous administration of snake antivenom and is not performed through any other route due to their lower efficacy and the need for rapid action of the snake antivenom ${ }^{(13-15)}$. Due identification of the snake provides a better management of care and the administration of an appropriate serum ${ }^{(16)}$.

Diverse factors interfere with the severity of snakebites, which may be related to the snake, to the time elapsed since the snakebite, to the patient, and to medical care. Treatment of Attacks by Venomous Animals in Brazil is classified and recommended according to the severity of the attack. Serotherapy for Bothrops bites classified as mild includes 2 to 4 ampules; moderate, 4 to 8 ampules; and severe, 12 ampules. In case of Crotalus bite, 5 ampules should be administered mild cases; moderate, 10 ampules; and severe, 20 ampules. For Lachesis bites, 10 to 20 ampules are recommended, whereas Elapid bites require that 10 ampules be administered ${ }^{(17)}$. When victims of mild and moderate snakebites receive care within six hours from the snakebite, their prognosis is usually favorable. However, patients who were bitten in the lower limb, if submitted to tourniquet and cared for after 6 hours from the snakebite, or if snake antivenom is administered incorrectly, the prognosis is less favorable and may progress to death. The application of substances such as tobacco, alcohol, coffee, manure, and others, is not recommended, which is also true of cutting and sucking, as these favor the development of local infections ${ }^{(18)}$.
The notification of snakebites is compulsory in $\mathrm{Brazil}^{(19)}$. This is an important public health problem in tropical and subtropical countries, leading to deaths and disabilities, particularly in South America. Regional analyses of snakebites provide an important contribution to understanding their distribution in Brazil ${ }^{(20-21)}$.

In Brazil, 28,601 snakebites were notified in 2017, 105 of which progressed to death. In the state of São Paulo, there were 2,218 cases in 2017, with 7 cases resulting in death; in the state of Amazonas, 1,594 cases and 8 deaths occurred; in the state of Bahia, 2,626 cases and 16 deaths; in the state of Pará, 4,832 snakebites and 13 cases of progression to death; in the state of Minas Gerais, there were 3,337 notifications of snakebite, 6 of which progressed to death; and in the health macro-region of Triângulo Sul, in the state of Minas Gerais, there were 171 snakebites and 1 death related to the notified case ${ }^{(22)}$.

Studies on venomous snakebites are also crucial to identify the most frequent types and the most affected groups to develop strategies for the distribution of specific antivenoms, in addition to helping in methods for snakebite prevention and guaranteeing better conditions of service and treatment for the victims ${ }^{(20)}$. Considering the scarcity of studies on snakebite in Brazil and other countries ${ }^{(5,23)}$, this study sought to understand the epidemiological and clinical profile of snakebite victims in a public teaching hospital.

\section{METHOD}

\section{Design OF STUDY}

This is a cross-sectional, retrospective study with a quantitative approach.

\section{Population}

This study's population was composed of patients who were victims of snakebite from June 2018 to May 2019 and admitted to a public teaching hospital in the Triângulo Sul region of the Brazilian state of Minas Gerais (MG). This hospital meets demands of 27 municipalities which constitute this macro-region and is the only one to offer highcomplexity care, providing services exclusively through the Unified Health System (Sistema Único de Saúde - SUS) and also receiving patients from other regions of $M G$ and various Brazilian states. Such institution responds for $73 \%$ of all moderate and high complexity care of the macro-region and $100 \%$ of high complexity in this area, except for cancer treatment, being the only hospital in the macro-region to offer serum treatment to patients attacked by venomous animals, including snake antivenom. Out of 302 active beds, 20 are in the pediatric ICU, 10 in the adult UCI, and 10 in the coronary ICU; there are also 14 surgery rooms and Emergency Service with 32 beds.

\section{SAMPLE}

The sample was composed of all patients who were victims of snakebite in the studied period. 


\section{SELECTION CRITERIA}

The enrollment criteria were patients who were victims of snakebite from June 2018 to May 2019.

\section{Data Collection}

The data were collected by a nurse through physical medical records of the patients and notification forms. Each medical record and notification form was carefully analyzed by observing the data and verifying information veracity. For each item analyzed in the notification form, a new verification was made in the patient's physical medical record, doubly confirming the information. A semi-structured script was employed to guide the data collection. It was created by the authors and included sociodemographic, clinical, eventrelated, and care-related variables; the script demanded information such as socioeconomic data, month of the accident, type of snake, bitten site, snakebite classification, number of administered ampules, local and systemic manifestations and complications, work-related snakebite, and case progression. The data collection period was 45 days.

\section{DATA TREATMENT AND ANALYSIS}

The data analysis was conducted in the program Statistical Package for the Social Sciences (SPSS) for Windows XP ${ }^{\circledR}$. Simple descriptive analysis was used to present the categorical variables, with the elaboration of tables with absolute frequency and percentages. For the quantitative variables, the central tendency values were calculated. Spearman test was applied to verify the correlation between the severity of the snakebite and the number of administered ampules.

\section{ETHICAL ASPECTS}

The project was approved by the Human Research Ethics Committee of Teaching Hospital of Universidade Federal do Triângulo Mineiro (CEP/HC-UFTM) in 2019 in protocol n. 3634273, in accordance with Resolution n. 466/12 by the National Health Council. During the research, participant confidentiality and anonymity were maintained.

\section{RESULTS}

The snakebite victims totaled 137 people. Concerning their education, most had not completed primary education, amounting to 50 people (36.5\%), followed by those who had completed secondary education, 36 people (26.3\%), and unreported, 30 people (21.9\%). Regarding skin color, most were brown, a total of 83 (60.3\%), followed by 45 (32.8\%) white persons (Table 1 ).

The patients receiving care in the study hospital are from the macro-region of Triângulo Sul, in the state of Minas Gerais. This macro-region includes the following municipalities: Água Comprida, Araxá, Campo Florido, Campos Altos, Carneirinho, Comendador Gomes, Conceição das Alagoas, Conquista, Delta, Fronteira, Frutal, Ibiá, Itapagipe, Iturama, Limeira do Oeste, Pedrinópolis, Perdizes, Pirajuba, Planura, Pratinha, Sacramento, Santa Juliana, São Francisco de Sales, Tapira, Uberaba, União de Minas, and Veríssimo. Most of the patients suffering with snakebite originated from municipalities composing the macro-region of Triângulo Sul, amounting to 104 (75.9\%), except for Uberaba, which is a reference center for the treatment of snakebite and had a total of 33 (24.1\%) snakebite victims in the study period.

Table 1 - Sociodemographic profile of snakebite victims receiving care in a public teaching hospital - Uberaba, MG, Brazil, 2019.

\begin{tabular}{|c|c|c|c|}
\hline Gender & $\mathbf{N}$ & $\%$ & \\
\hline Male & 102 & 74.5 & \\
\hline Female & 35 & 25.5 & \\
\hline Minimum age & Maximum age & Mean & Standard deviation \\
\hline 3 years & 86 years & 43.49 & 18.31 \\
\hline \multicolumn{4}{|c|}{ Origin } \\
\hline & $\mathbf{N}$ & $\%$ & \\
\hline $\begin{array}{l}\text { Municipality } \\
\text { of Uberaba }\end{array}$ & 33 & 24.1 & \\
\hline $\begin{array}{l}\text { Other } \\
\text { municipalities }\end{array}$ & 104 & 75.9 & \\
\hline Total & 137 & 100.0 & \\
\hline \multicolumn{4}{|c|}{ Employment status } \\
\hline & $\mathbf{N}$ & $\%$ & \\
\hline Unreported & 48 & 35.0 & \\
\hline Rural workers & 46 & 33.4 & \\
\hline $\begin{array}{l}\text { Other } \\
\text { professions }\end{array}$ & 17 & 12.2 & \\
\hline Housewife & 11 & 8.0 & \\
\hline Retired & 09 & 6.6 & \\
\hline Student & 06 & 4.4 & \\
\hline Total & 137 & 100 & \\
\hline
\end{tabular}

The months with the highest number of snakebite cases were April, with 19 cases (13.9\%); October, 17 cases (12.4\%); and May, 16 cases (11.7\%). The weather in such months is dry in the studied region. However, high percentages of snakebite were observed in March, with 15 cases (10.9\%); November, 14 cases (10.2\%); and January, 13 cases (9.5\%). Such months are related to the rain period which is characteristic of the Southeast region.

Most accidents, 120 (87.6\%), took place in rural areas. In urban areas, there were only 17 (12.4\%). The most common snake genera involved in snakebites were Bothrops and Crotalus, which, when summed, amounted to $91.2 \%$ (Table 2).

Table 2 - Snake genera involved in snakebites - Uberaba, MG, Brazil, 2019.

\begin{tabular}{lcc}
\hline Snake genera & N & $\%$ \\
\hline Bothrops & 97 & 70.8 \\
Crotalus & 28 & 20.4 \\
Micrurus & 1 & 0.7 \\
Unreported & 11 & 8.0 \\
\hline Total & $\mathbf{1 3 7}$ & $\mathbf{1 0 0 . 0}$ \\
\hline
\end{tabular}


As for the classification of these snakebites, most, 73 (53.3\%), were mild, followed by 44 (32.1\%) moderate cases, and $20(14.6 \%)$ severe cases. The most affected body parts were the lower limbs, followed by the upper limbs. The leg, with 49 (35.8\%) cases; foot, 47 (34.3\%) cases; and hand, 34 (24.8\%) cases, stand out.

Regarding time between accident and start of treatment, an interval of one to four hours was observed in 97 occurrences $(70.8 \%)$ and five to ten hours in 33 (24.1\%). Therefore, most received care within 10 hours (Table 3 ).

Table 3 - Time between snakebite and care - Uberaba, MG, Brazil, 2019.

\begin{tabular}{lcc}
\hline Time & N & $\%$ \\
\hline 1h to $4 \mathrm{~h}$ & 97 & 70.8 \\
$5 \mathrm{~h}$ to $10 \mathrm{~h}$ & 33 & 24.1 \\
12h to $24 \mathrm{~h}$ & 5 & 3.6 \\
Over $24 \mathrm{~h}$ & 2 & 1.5 \\
\hline Total & $\mathbf{1 3 7}$ & $\mathbf{1 0 0 . 0}$ \\
\hline
\end{tabular}

Most snakebite victims, 100 (73\%), received snake antivenom, whereas 37 (27\%) did not receive it (Table 4).

Table 4 - Number of ampules administered in care of snakebite victims - Uberaba, MG, Brazil, 2019.

\begin{tabular}{lcc}
\hline Number of Ampules & N & \% \\
\hline None & 37 & 27.0 \\
3 to 5 ampules & 39 & 28.5 \\
6 to 10 ampules & 42 & 30.7 \\
12 to 30 ampules & 19 & 13.9 \\
\hline Total & $\mathbf{1 3 7}$ & $\mathbf{1 0 0 . 0}$ \\
\hline
\end{tabular}

Among local and systemic manifestations, pain was present in 132 (96.4\%) cases, most of them; edema was present in $89(65 \%)$; and altered coagulation in $76(55.5 \%)$. As for the local and systemic complications, the most prevalent ones were secondary infection, in $45(32.8 \%)$ cases, and kidney failure, in 10 (7.3\%) (Table 5).

Table 5 - Local and systemic manifestations and complications identified in snakebite victims - Uberaba, MG, Brazil, 2019.

\begin{tabular}{lcc}
\hline Local manifestation & $\mathrm{N}$ & $\%$ \\
\hline Pain & 132 & 96.4 \\
Edema & 89 & 65.0 \\
Ecchymosis & 13 & 9.5 \\
Erythema & 5 & 3.6 \\
Others & 46 & 33.6 \\
\hline Systemic manifestation & $\mathrm{N}$ & $\%$ \\
\hline Altered coagulation & 76 & 55.5 \\
Vagal & 29 & 21.2 \\
Neuroparalytic & 27 & 19.7 \\
Kidney & 8 & 5.8 \\
Hemorrhagic & 7 & 5.1 \\
Myolytic & 7 & 5.1 \\
Others & 13 & 9.5 \\
\hline
\end{tabular}

\begin{tabular}{lcc}
\hline ...continuation & $\mathrm{N}$ & $\%$ \\
\hline Local complication & 45 & 32.8 \\
Compartment syndrome & 6 & 4.4 \\
Extensive necrosis & 1 & 0.7 \\
\hline Systemic complication & $\mathrm{N}$ & $\%$ \\
\hline Kidney failure & 10 & 7.3 \\
Respiratory insufficiency & 4 & 2.9 \\
Shock & 1 & 0.7 \\
\hline
\end{tabular}

Most snakebites were not work-related and progressed with referral to other services, i.e., outpatient network and the basic health units of SUS; therefore, only one death by snakebite was registered.

Concerning classification by snakebite severity and the number of administered ampules, Spearman correlation test was significant $(\mathrm{p}<0.01$; Spearman 0.874).

\section{DISCUSSION}

In this study, most snakebite victims were male and were in their working age, corroborating other similar studies $^{(16,24-26)}$.

Most had not finished primary education, followed by complete secondary education, and unreported, which is related to the profession of study participants, who were to a great extent (33.4\%) rural workers, including mid-level workers in farms and manual workers. Considering the high number of unreported professions and education, the importance of filling all fields of the notification forms appropriately is emphasized; this corroborates findings of a qualitative study in Paraíba and of an exploratory and descriptive study in the state of Goiás, in which most snakebites affected rural workers ${ }^{(23-24)}$.

The study region has a tropical climate, with seasonality and summer between October and March, with more abundant rains and higher temperatures; however, rain can be observed by the second half of September due to the decline of the dry season and winter characterized by lower temperatures and a dry weather ${ }^{(27)}$. The months with the highest number of snakebites were April, October, and May, which present dry weather in the studied region. However, high percentages of snakebites were observed in March, November, and January. These are related to the rain period which is characteristic of Southeast Brazil. In similar studies, the months with most snakebites coincided with the start and the end of rain periods. Recognizing periods with the highest occurrence of snakebites is important to prepare services to a higher demand of care and request appropriate amounts of snake antivenom, as well as establishing strategies for snakebite prevention, such as educating farm workers, reinforcing the need for using personal protective equipment, and educating the general population not to store garbage at home, as this is attractive for rodents, which are attractive to snakes searching for food, as shown by other studies ${ }^{(5-6,24,27-28)}$.

As for the care of snakebite victims, most were verified to come from neighboring municipalities which compose the 
macro-region of Triângulo Sul (except for Uberaba). More intense rural activity is observed in these municipalities, and snakebites have occurred mostly in rural areas, which corroborates findings of a descriptive, quantitative, retrospective study conducted in the municipality of Teresópolis, Rio de Janeiro, with 121 cases of snakebite ${ }^{(21)}$.

The genera Bothrops is the most often involved in snakebites in Brazil, which is also shown in this study, as well as in findings of a descriptive, quantitative, and cross-sectional study with 91 cases occurred in Rondônia ${ }^{(16)}$. The snakes of the genera Bothrops are characterized by their capacity to adapt to different environments and they may thus be found in diverse areas in $\mathrm{Brazil}^{(26)}$. The most commonly bitten parts were legs, feet, and hands; most snakebites were mild, corroborating findings of similar studies ${ }^{(6,16,21,24,29)}$.

Snakebite victims generally seek rapid medical care, according to findings of a descriptive, cross-sectional study conducted in a municipality of Paraíba, with 3,033 cases $^{(20)}$. Most study participants received care less than 6 hours from the snakebite. The importance of the variable time in snakebites is emphasized, since the longer patients wait for appropriate care, the higher is the correlation with local and systemic complications.

In this study, most participants have received treatment with intravenous snake antivenom; antibothropic antivenom was the most administered, which corroborates findings of a care report, a descriptive, quantitative, cross-sectional study, and a descriptive, quantitative, and retrospective study ${ }^{(15-16,21)}$. Most victims received 6 to 10 ampules followed by 3 to 5 ampules and 12 to 30 ampules, which is equivalent to the recommended amount, respectively, for moderate, mild, and

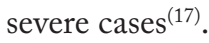

The local and systemic manifestations were pain, edema, altered coagulation, and neuroparalytic and vagal complications, which corresponds to findings of a retrospective and a cross-sectional study ${ }^{(29-30)}$. The local and systemic complications were observed to be secondary infection, compartment syndrome, and kidney failure, which were also found in a retrospective study in a metropolitan region in Northeast Brazil, in which 1,063 cases of snakebite were analyzed ${ }^{(29)}$.

The snakebite victims were mostly not performing professional activities during the occurrence. In a descriptive study with 641 patients, a major part of snakebites was observed to be work-related ${ }^{(24)}$.

In clinical progression, patients were mostly referred to some other health service, such as basic health units and outpatient network of SUS for treatment or follow-up, with subsequent cure. Only one death was found in the study period, which suggests the correct treatment of these patients. In a qualitative, descriptive, and retrospective study conducted in the municipality of Teresópolis with 121 patients, most snakebite victims were observed to have been cured $^{(21)}$.

The correlation between the variables severity and number of ampules, as per Spearman test, was significant, which showed an appropriate management in the treatment of snakebites in the study hospital, since, the higher its severity, the more due snake antivenom ampules were received by the patients, corroborating findings of a descriptive, quanti-qualitative, cross-sectional, and retrospective field study with 91 patients $^{(16)}$. In a retrospective study with 195 patients, cases of under- and overdosing have been observed for serum administration ${ }^{(5)}$.

As a limitation, this study has found flaws in the process of filling some case notification forms, which emphasizes the epidemiological importance of filling these forms appropriately. This limitation was overcome by jointly analyzing each patient's medical records, since some information which was absent from the files were found in the medical records. However, sociodemographic information was lost with the incorrect filling of the notification forms. The scarcity of studies on snakebite in Brazil and other countries is considered a limitation. This study has thus contributed to the appropriate planning of health policies for providing care to snakebite victims, as well as strategic measures for its prevention.

\section{CONCLUSION}

Snakebites affected mostly men in their working age and rural workers. Accidents with the genus Bothrops and classified as mild were prevalent. These were mostly treated with appropriate snake antivenom. The most common setting was the rural area. The most prevalent bitten body areas were feet, leg, and hand. Services were provided in less than six hours. The most relevant local and systemic manifestations were pain, edema, altered coagulation, vagal and neuroparalytic, whereas the complications were secondary infection, compartment syndrome, and kidney failure.

In the victims' clinical progression, a high number of referrals to other services was observed, and there was only one death by this aggravation in the period. According to the statistical analysis, there was a correlation between severity and the number of ampules, since the more severe the snakebite, the more due snake antivenom ampules were received by the patients.

\section{RESUMO}

Objetivo: Conhecer o perfil epidemiológico e clínico das vítimas de acidente ofídico em um hospital público de ensino. Método: Estudo exploratório, descritivo, transversal, de abordagem metodológica quantitativa, realizado em um hospital público do Triângulo Sul de Minas Gerais. A coleta de dados foi realizada em prontuários e fichas de notificação compulsória de pacientes admitidos no Pronto Socorro de junho de 2018 a maio de 2019. Os dados foram analisados descritivamente e apresentados em forma de tabelas. Resultados: De um total de 137 pacientes, foram predominantes o sexo masculino (74,5\%), trabalhadores rurais (33,4\%), indivíduos em idade produtiva (média de 43,49 anos) e zona de ocorrência rural (87,6\%). O gênero mais envolvido nos acidentes foi o Bothrops (70,8\%) e a classificação da maioria foi leve (53,3\%). O tratamento mais realizado foi a administração do soro antiofídico (73\%). Conclusão: Os acidentes ofídicos aconteceram majoritariamente em homens em idade produtiva e trabalhadores rurais. Prevaleceram os acidentes pelo gênero Bothrops e classificados como leves. A maioria dos tratamentos utilizou soro antiofídico adequado. A zona de maior ocorrência foi a rural. As áreas corporais prevalentes de mordedura foram pé, perna e mão e os atendimentos foram realizados em menos de 6 horas. 
DESCRITORES

Perfil de Saúde; Mordeduras de Serpentes; Venenos de Serpentes; Serviços Médicos de Emergência; Enfermagem em Emergência.

\section{RESUMEN}

Objetivo: Conocer el perfil epidemiológico y clínico de las víctimas de accidentes ofídicos en un hospital público docente. Método: Estudio exploratorio, descriptivo, transversal, con enfoque metodológico cuantitativo, realizado en un hospital público de la región del Triângulo Sul del estado de Minas Gerais, Brasil. Los datos se recogieron de las historias clínicas y formularios de notificación obligatoria de los pacientes ingresados en los Servicios de Urgencia desde junio de 2018 hasta mayo de 2019. Los datos se analizaron de forma descriptiva y se presentaron en forma de tablas. Resultados: De un total de 137 pacientes, predominaron el sexo masculino $(74,5 \%)$, los trabajadores rurales $(33,4 \%)$, los individuos en edad productiva (media de 43,49 años) y la zona de ocurrencia rural (87,6\%). El género más implicado en los accidentes fue el Bothrops $(70,8 \%)$ y la clasificación de la mayoría fue leve (53,3\%). El tratamiento más común fue la administración del suero antiofídico (73\%). Conclusión: Los accidentes ofídicos se produjeron sobre todo en hombres en edad productiva y en trabajadores rurales. Prevalecieron los accidentes por el género Bothrops y los que se clasifican como leves. La mayoría de los tratamientos utilizaron el antiofídico adecuado. La zona más común de ocurrencia fue la rural. Las zonas corporales más afectadas por las mordeduras fueron los pies, las piernas y las manos, y los tratamientos se realizaron en menos de 6 horas.

\section{DESCRIPTORES}

Perfil de Salud; Mordeduras de Serpientes; Venenos de Serpientes; Servicios Médicos de Urgencia; Enfermería de Urgencia.

\section{REFERENCES}

1. World Health Organization. Control of negleted tropical diseases [Internet]. Genebra:WHO; 2020 [cited 2019 Jan 14]. Available from: http://www.who.int/neglected_diseases/diseases/en/

2. Mendonça-da-Silva I, Tavares AM, Sachett J, Sardinha JF, Zaparolli L, Santos MFG, et al. Safety and efficacy of a freeze-dried trivalent antivenom for snakebites in the Brazilian Amazon: an open randomized controlled phase Ilb clinical trial. PLoS Negl Trop Dis. 2017;11(11):e0006068. doi: https://doi.org/10.1371/journal.pntd.0006068

3. Silva AM, Bernarde PS, Abreu LC. Accidents with poisonous animals in Brazil by age and sex. J Hum Growth Dev. 2015;25(1):54-62. doi: http://dx.doi.org/10.7322/JHGD.96768

4. González Manrique G, Motta O, Ramírez C, Peña L. Oftalmoplejía asociada a neurotoxicidad por veneno de serpiente: presentación de un caso y revisión de la literatura. Acta Neurol Colomb. 2016;314-9. doi: https://doi.org/10.22379/24224022114

5. Bernarde PS, Gomes J de O. Serpentes peçonhentas e ofidismo em Cruzeiro do Sul, Alto Juruá, Estado do Acre, Brasil. Acta Amazon. 2012;42(1):65-72. doi: https://doi.org/10.1590/S0044-59672012000100008

6. Guimarães CD, Palha MC, Silva JC. Perfil clínico-epidemiológico dos acidentes ofídicos ocorridos na Ilha de Colares, Pará, Amazônia oriental. Semina Ciênc Biol Saúde. 2015;36(1):67-78. doi: https://dx.doi.org/10.5433/1679-0367.2015v36n1p67

7. Gutiérrez JM, Warrell DA, Williams DJ, Jensen S, Brown N, Calvete JJ, et al. The need for full integration of snakebite envenoming within a global strategy to combat the neglected tropical diseases: The Way Forward. PLoS Negl Trop Dis. 2013;7(6):e2162. doi: https://doi. org/10.1371/journal.pndt.0002162

8. Alonso A, Vera R, Silva EO, Portillo C, Miret J, Canese J, et al. Accidentes ofídicos notificados al Programa Nacional de Control de Zoonosis y Centro Antirrábico Nacional, Paraguay (2015). Rev Salud Pública Parag [Internet]. 2018 [citado 2019 maio 15];8(2):40-4. Disponible en: http://revistas.ins.gov.py/index.php/rspp/article/view/517/413

9. Animais venenosos: serpentes, anfíbios, aranhas, escorpiões, insetos e lacraias [Internet]. 2. ed. São Paulo: Instituto Butantan; 2013 [citado 2019 dez. 10]. Disponível em: https://publicacoeseducativas.butantan.gov.br/web/animais-venenosos/pages/pdf/animais_venenosos.pdf

10. Chippaux, JP. Incidence and mortality due to snakebite in the Americas. PLoS Negl Trop Dis, 2017;11(6):e0005662. doi: https://doi. org/10.1371/journal.pntd.0005662

11. Silva KRLM, Marques MGBM, Nicolella A. Manual de acidentes por animais peçonhentos e venenosos para agentes comunitários de saúde. Porto Alegre: CIT/RS; 2016.

12. Keyler DE, Saini V, Mark O'Shea M, Gee J, Smith CF, Mackessy SP. Crotalus oreganus concolor: envenomation case with venom analysis and a diagnostic conundrum of myoneurologic symptoms. Wilderness Environ Med. 2020;31(2):220-5. doi: https://doi.org/10.1016/j. wem.2019.12.007

13. Brasil. Ministério da Saúde. Guia de Vigilância Epidemiológica [Internet]. 7. ed. Brasília; 2009 [citado 2020 fev. 20]. Disponível em: http:// bvsms.saude.gov.br/bvs/publicacoes/guia_vigilancia_epidemiologica_7ed.pdf

14. Oliveira ATAL, Sousa AFPB, Alcantara ICL, Miranda ITN, Marques RB. Acidentes com animais peçonhentos no Brasil: revisão de literatura. Revinter. 2018;11(03):119-36. doi: https://doi.org/10.22280/revintervol11ed3.389

15. Greene S, Galdamez LA, Tomasheski R. White-Lipped Tree Viper (Cryptelytrops albolabris) Envenomation in an American Viper Keeper. J Emerg Med. 2017;53(6):e115-8. doi:10.1016 / j.jemermed.2017.09.003

16. Santos AA, Vizotto RM, Souza LP, Lima MG, Viana TCT. Perfil clínico-epidemiológico dos pacientes vítimas de acidentes ofídicos no município de Cacoal, Rondônia, Brasil, no período de 2009 a 2013. J Health Biol Sci. 2017;5(3):221. doi: http://dx.doi.org/10.12662/23173076jhbs.v5i3.1275.p221-227.2017

17. Brasil. Ministério da Saúde. Manual de diagnóstico e tratamento de acidentes por animais peçonhentos [Internet]. Brasília: Funasa; 2001. [citado 2019 mar. 05]. Disponível em: https://www.icict.fiocruz.br/sites/www.icict.fiocruz.br/files/Manual-de-Diagnostico-e-Tratamentode-Acidentes-por-Animais-Pe--onhentos.pdf

18. Oliveira LP, Moreira JGV, Sachett JAG, Monteiro WM, Meneguetti DUO, Bernarde PS. Snakebites in Rio Branco and surrounding region, Acre, Western Brazilian Amazon. Rev Soc Bras Med Trop. 2020;53:e20200214. doi: 10.1590/0037-8682-0214-2020 
19. Cupo P. Bites and stings from venomous animals: a neglected Brazilian tropical disease. Rev Soc Bras Med Trop. 2015;48(6):639-41. doi: https://doi.org/10.1590/0037-8682-0387-2015

20. Saraiva MG, Oliveira DS, Fernandes Filho GMC, Coutinho LASA, Guerreiro JV. Perfil epidemiológico dos acidentes ofídicos no Estado da Paraíba, Brasil, 2005 a 2010. Epidemiol Serv Saúde. 2012;21(3):449-56. doi: http://dx.doi.org/10.5123/S1679-49742012000300010

21. Rita TS, Sisenando HA, Machado C. Análise epidemiológica dos acidentes ofídicos no município de Teresópolis - RJ no período de 2007 a 2010. Rev Ciênc Plur [Internet]. 2016 [citado 2019 jun. 25];2(2):28-40. Disponível em: https://periodicos.ufrn.br/rcp/article/ view/9639/8402

22. Brasil. Ministério da Saúde; DATASUS. Informações de Saúde (TABNET): Epidemiológicas e Morbidade [Internet]. 2019 [citado 2019 abr. 16]. Disponível em: http://www2.datasus.gov.br/DATASUS/index.php?area=0203

23. Sarkhel S, Ghosh R, Mana K, Gantait K. A hospital based epidemiological study of snakebite in Paschim Medinipur District, West Bengal, India. Toxicol Rep. 2017;4:415-9. doi: https://doi.org/10.1016/j.toxrep.2017.07.007

24. Nunes DCO, Franco PS, Rodrigues VM, Mendes MM. Clinical-epidemiologic aspects of ophidian acidentes occurred in Triângulo Mineiro Region, Minas Gerais State, Brazil: retrospective case series. Biosci J [Internet]. 2014 [cited 2019 May 18];30(6):1942-51. Available from: http://www.seer.ufu.br/index.php/biosciencejournal/article/view/22442

25. Gonçalves RC, Faleiro JH, Lima GM, Malafaia G, Castro ALS. The epidemiology of snakebite accidents in the cities of southeast Goias from 2007 to 2011. Biosci J [Internet]. 2014 [cited 2019 June 02];30(5):9. Available from: http://www.seer.ufu.br/index.php/biosciencejournal/ article/view/27479/15038

26. Oliveira HFA, Costa CF, Sassi R. Relatos de acidentes por animais peçonhentos e medicina popular em agricultores de Cuité, região do Curimataú, Paraíba, Brasil. Rev Bras Epidemiol. 2013;16(3):633-43. doi: https://doi.org/10.1590/S1415-790X2013000300008

27. Minuzzi RB, Sediyama GC, Barbosa EM, Melo Júnior JCF. Climatologia do comportamento do período chuvoso da região sudeste do Brasil. Rev Bras Meteorol. 2007;22(3):338-44. doi: https://doi.org/10.1590/S0102-77862007000300007

28. Brasil. Ministério da Saúde. Guia de vigilância epidemiológica [Internet]. 6. ed. Brasília; 2005 [citado 2019 mar. 20]. Disponível em: http://bvsms.saude.gov.br/bvs/publicacoes/Guia_Vig_Epid_novo2.pdf

29. Santana, CR, Oliveira MG. Avaliação do uso de soros antivenenos na emergência de um hospital público regional de Vitória da Conquista (BA), Brasil. Ciênc Saúde Coletiva. 2020;15(3):869-78. doi: https://doi.org/10.1590/1413-81232020253.16362018

30. Albuquerque PLMM, Silva Junior GB, Jacinto CN, Lima CB, Lima JB, Veras MSB, et al. Perfil epidemiológico dos acidentes por picada de cobra em região metropolitana do nordeste do Brasil. Rev Inst Med Trop São Paulo. 2013;55(5):347-51. doi: https://doi.org/10.1590/ S0036-46652013000500009 